\title{
SUPPLEMENTATION OF FRUCTOOLIGOSACCHARIDES (FOS) ON FAECAL CHARACTERISTICS OF ADULT DOGS
}

\author{
Ananda Portella Félix ${ }^{1}$, Cleusa Marcon Brito ${ }^{1}$, Carolina Pedro Zanatta1, Daniele \\ Cristina Lima1 ${ }^{1}$ Simone Gisele Oliveira ${ }^{1}$, Alex Maiorka1 \\ 1 UFPR \\ Correspondência: Ananda Portella Félix: ananda_felix@yahoo.com.br
}

\begin{abstract}
The faecal characteristics of dogs fed three FOS dietary inclusion levels $(0.000,0.047$, or $0.095 \%$ ) were evaluated. Fifteen adult dogs were used. A completely randomized experimental design in split-plot, with five days of faeces collection and five dogs per experimental diet was applied, resulting in a total of 25 observations per treatment. Diets were offered to the dogs for a 25day adaptation period, followed by five days of total faeces collection. Means were compared by Tukey-Kramer's test. The faeces of dogs fed the diet with no FOS presented lower dry matter content and lower faecal score than dogs fed 0.047 or $0.095 \%$ FOS, which presented similar faecal characteristics. Faecal pH of dogs supplemented with $0.095 \%$ FOS was lower than the faeces of dogs fed 0.047 or $0.000 \%$ FOS. Faecal ammonia concentration and faecal output were similar among treatments. The supplementation of $0.095 \%$ FOS reduces faecal $\mathrm{pH}$ and improves faecal consistency of dogs.

Key Words: gut health, oligosaccharides; prebiotics
\end{abstract}

\section{SUPLEMENTAÇÃO DE FRUTOOLIGOSSACARÍDEOS SOBRE AS CARACTERÍSTICAS DAS FEZES DE CÃES}

RESUMO: Foram avaliadas as características das fezes de cães alimentados com três níveis de inclusão de FOS $(0.000 ; 0.047$ e $0.095 \%)$ na dieta. Foram utilizados 15 cães adultos da raça Beagle. O experimento seguiu delineamento inteiramente ao acaso em parcela subdividida no tempo, com cinco dias de colheita de dados e cinco cães recebendo cada tratamento, totalizando 25 observações por tratamento. As dietas foram oferecidas aos cães por um período de adaptação de 25 dias seguidos por cinco dias de colheita total de fezes. As médias foram comparadas pelo teste Tukey-Kramer. Os cães alimentados com a dieta sem inclusão de FOS apresentaram fezes com menor teor de matéria seca e menor escore em relação aos animais que receberam 0.047 ou $0.095 \%$ de FOS na dieta, os quais não diferiram entre si. O pH fecal de cães suplementados com $0.095 \%$ de FOS foi menor do que o dos cães que receberam 0.047 ou $0.000 \%$ de FOS. O teor de amônia fecal e a quantidade de fezes excretadas não diferiram entre os tratamentos. A suplementação com $0.095 \%$ de FOS na dieta reduz o pH e aumenta a consistência fecal de cães.

Palavras-chave: oligossacarídeos; prebiótico; saúde intestinal 


\section{INTRODUCTION}

Fructooligosaccharides (FOS) are natural oligosaccharides consisting of a chain of fructose residues linked $\beta$ (2-1) bonds and a terminal glucose. They may contain from two to 60 monomers (Hussein et al., 1998).

FOS may be considered as a kind of soluble dietary fiber (Cummings \& Englyst, 1995); however, they do not increase intestinal content viscosity, and probably do not significantly influence nutrient digestibility (Schneeman, 1999). They also be considered prebiotics, as, according to Gibson \& Roberfroid (1995), a prebiotic is a feed ingredient that cannot be digested by the enzymes in the small intestine, and that benefits the body by selectively stimulating the growth and/or activity of some bacteria in the colon that promote the host's health.

Studies have demonstrated that FOS supplementation improves intestinal health in dogs (Russell, 1998; Swanson et al., 2002a; Middelbos et al., 2007). FOS are not hydrolyzed in the small intestine, and reach the large intestine, where they are fermented by the local microbiota, producing shortchain fatty acids (SCFA), lactate, and gases. This reduces intestinal $\mathrm{pH}$, promoting the growth of beneficial intestinal microorganisms, such as Bifidobacterium spp. and Lactobacillus spp., and inhibiting pathogenic microorganisms, including Clostridium, E. coli, Listeria, Shigella, Salmonella, etc. (Beynen, 2003). In addition, FOS supplementation may reduce the production of putrefactive compounds (phenol, indole, ammonia, etc.), which result in the unpleasant smell of faeces and may contribute for colon carcinogenesis (Swanson et al., 2002a). On the other hand, excessive FOS intake may increase intraluminal osmotic pressure, causing faster intestinal transit, discomfort, flatulence, and cramps. Therefore, adequate FOS levels must be included in the diet.

The objective of the present study was to evaluate the effect of increasing dietary FOS levels on faecal characteristics of dogs.

\section{MATERIAL AND METHODS}

Fifteen four-year-old male and female Beagles from the kennel of Laboratory of Dog Nutrition Studies (Laboratório de Estudos de Nutrição Canina - LENUCAN), of the School of Agricultural Sciences of the Federal University of Paraná (UFPR), Brazil, were used in the experiment. Dogs had been previously vaccinated and dewormed, and weighed (13.40 \pm 1.73 $\mathrm{kg}$ ). The experimental procedures were approved by the Animal Ethics Committee of that University.

Three FOS levels $(0.000,0.047$, and $0.095 \%$ ) were included in a commercial dry extruded adult dog food (Table 1). FOS levels were obtained by adding $0.00,0.05$, or $0.10 \%$, respectively, of Fortifeed®P95, a shortchain FOS (glucose terminated molecules with two to four fructose units, attached by $\beta(2-1)$ glycosidic linkages) extracted from sugarcane, with 95\% purity, and two to four degree of polymerization.

Table 1 - Ingredient and chemical composition of the experimental diet.

\begin{tabular}{lc}
\hline Ingredient & $\mathrm{g} . \mathrm{kg}^{-1}$ \\
\hline Corn & 440.0 \\
Brewers rice & 40.0 \\
Soybean meal & 150.0 \\
Meat and bone meal & 150.0 \\
Fish meal & 10.0 \\
Poultry offal meal & 140.0 \\
Poultry fat & 35.0 \\
Flavour & 25.0 \\
Vitamin and mineral premix & 5.0 \\
Sodium chloride & 5.0 \\
\hline \multicolumn{2}{l}{} \\
\hline Dry matter\% & 89.36 \\
& $\%$ of DM \\
Organic matter & 90.04 \\
Ash & 9.96 \\
Crude protein & 30.59 \\
Acid ether extract & 8.51 \\
Crude fibre & 2.34 \\
Nitrogen-free extract & 37.96 \\
Metabolizable energy (kcal. $\mathrm{g}^{-1}$ ) & 3.12 \\
\hline
\end{tabular}

Vitamin and mines al premix ( $(9 \mathrm{~d} \mathrm{~kg}$.food-1) : Vit. A $-20,000 \mathrm{IU}$. Vit. D $-2,000 \mathrm{IU}$, Vit. E- $48 \mathrm{mg}$, Vit. K $48 \mathrm{mg}$. Vit. B1 - $4 \mathrm{mg}$, Vit. B2 $-32 \mathrm{mg}$. Pantothenic acid $-16 \mathrm{mg}$. Niscin $-58 \mathrm{mg}$. Choline $-800 \mathrm{mg}$. $\mathrm{mg}$ and antioxidant - $240 \mathrm{mg}$. 
The experiment followed a completely randomized design, in splitplot, with five days (sub-plot factor) of faecal sample collection and with five dogs feeding each treatment (main-plot factor), in a total of 25 observations per treatment. Diets were offered to the dogs for an adaptation period of 25 days, followed by a five days of total faecal collection period, with dogs housed in indoor/outdoor kennels until day 23, when they were placed in individual cages $(0.7 \times 0.6 \times 0.5 \mathrm{~m})$ for seven days (two days of adaptation and five days of total faeces collection).

The experimental diets were offered once daily at 7:30h. Food allowance was calculated as the amount required to supply the dogs' maintenance energy requirement (MER) as MER (kcal/day) $=130 \times$ Body weight $^{0.75}$, according to the NRC (2006). Dogs had free access to water. All faeces were collected fresh (up to 15 minutes after excretion), weighed, and submitted to the laboratory for chemical analyses.

The following faeces characteristics were evaluated: faecal score, dry matter (DM), ammonium nitrogen, $\mathrm{pH}$, and faecal output. Faecal score was determined always by the same researcher, according to a scale from 1 to 5, as follows: 1 = watery (liquid, can be poured from a container); 2 = soft, unshaped stool (assumes the shape of the container); $3=$ soft, shaped, and moist stool; $4=$ firm, shaped, dry stool (remains firm and soft) 5 = hard, dry pellets (small, hard masses) (Sá Fortes, 2005).

Fresh faeces from each individual dog were homogenized, and a sample was taken to determine ammonium nitrogen, according to the AOAC (1995). Faecal $\mathrm{pH}$ was measured in fresh faeces $(2 \mathrm{~g}$ fresh faeces diluted in $20 \mathrm{~mL}$ distilled water) and in faeces dried at $55^{\circ} \mathrm{C}$ for 48 hours $(2 \mathrm{~g}$ dried faeces diluted in $20 \mathrm{~mL}$ distilled water), always using a digital pHmeter, according to WALTER et al. (2005). The remaining faeces were dried in a forced-ventilation oven at $55^{\circ} \mathrm{C}$ for 72 hours, after which, DM content at $105^{\circ} \mathrm{C}\left(\mathrm{DM}_{\left.105^{\circ} \mathrm{C}\right)}\right.$ was determined in order to calculate original $\mathrm{DM}$ percentage as $\mathrm{ODM}=\left(\mathrm{DM}_{55^{\circ} \mathrm{C}} \mathrm{x}\right.$ $\mathrm{DM}_{\left.\left.105^{\circ} \mathrm{C}\right) / 100\right] \text {. }}$

Data were submitted to analysis of variance using the Mixed procedures of SAS (1999) statistical package. Means were compared by the test of TukeyKramer at 5\% probability level.

\section{RESULTS AND DISCUSSION}

All dogs consumed the total amount of the food offered. There was no difference in the food intake (243 $\mathrm{g}$ $\mathrm{DM} / \mathrm{dog} /$ day \pm 2.9 ) regardless of the FOS supplementation. The FOS intake was $0,0.11$, and $0.23 \mathrm{~g} / \mathrm{dog} / \mathrm{day}$. There were no effects of the day, neither interactions between day vs. treatments.

Faecal texture, in addition of being an important parameter in the assessment of dog foods, is also an indication of intestinal health. In the present study, the faeces of the dogs fed the diet with no FOS inclusion presented lower DM content and lower faecal score $(\mathrm{P}<0.05)$ as compared to those fed 0.047 or $0.095 \%$ FOS, which were different from each other $(P>0.05)$ (Table 2).

Table 2 - F aecal characteristics of dogs fed diets with different levels of FOS.

\begin{tabular}{|c|c|c|c|c|}
\hline & \multicolumn{3}{|c|}{ FOS levels (\%) } & \multirow[b]{2}{*}{ CV $(\%)$} \\
\hline & 0.000 & 0.047 & 0.095 & \\
\hline Faecal score & $2.5^{\mathrm{a}}$ & $3.2^{\circ}$ & $3.4^{\circ}$ & 15.81 \\
\hline Dry matter $\%$ & $34.8^{\mathrm{a}}$ & $38.2^{\circ}$ & $38.9^{\circ}$ & 4.43 \\
\hline $\mathrm{pH}$ of fresh faeces & $6.54^{\mathrm{a}}$ & $6.57^{\mathrm{a}}$ & $6.34^{\circ}$ & 2.74 \\
\hline $\mathrm{pH}$ of dry faeces & $6.17^{\mathrm{a}}$ & $6.19^{\mathrm{a}}$ & $6.08^{\circ}$ & 1.12 \\
\hline Ammonium nitrogen \% & 0.25 & 0.28 & 0.25 & 21.09 \\
\hline gfae. $\mathrm{kgBW}^{-1}$. day ${ }^{-1}$ & 15.12 & 14.44 & 14.06 & 39.76 \\
\hline
\end{tabular}

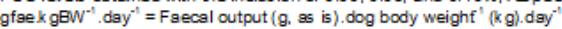

The SCFA resulting from FOS fermentation by the colon microbiota are rapidly absorbed by colonic cells, and therefore are the main anions responsible for water resorption by 
osmosis in the intestine (Herschel et al., 1981). However, the osmotic and resorption properties of SCFA appear to be dose dependent. At extremely low or high concentrations, SCFA are expected to increase faecal water content, whereas moderate SCFA concentrations generally decrease faecal water content (NRC, 2006).

Twomey et al. (2003), working with FOS dietary supplementation levels of $0.0,3.0$, or $6.0 \%$, observed lower DM content and worse faecal score in dogs fed the highest FOS inclusion level. This is mainly due to the physical effects and to the increase in luminal osmotic pressure caused by the non-fermentable fraction and the end products of the fermentation process, such as lactate. However, according to Strickling et al. (2000), the inclusion of oligosaccharides in dog foods at levels lower than $0.5 \%$ DM do not negatively affect nutrient digestibility or faecal texture.

Dogs supplemented with $0.095 \%$ FOS presented lower faecal $\mathrm{pH}$ $(P<0.05)$ than those fed 0.047 or $0.00 \%$ FOS (Table 2). Similar results were obtained by Twomey et al. (2003), who reported faecal $\mathrm{pH}$ reduction as FOS intake increased due to higher production of lactate. End products of fermentation influence the concentration of acids in the faeces, and therefore, when there is high availability of substrate in the large intestine, there is more fermentation, with consequent accumulation of acids, resulting in lower intestinal $\mathrm{pH}$, and hence, lower faecal $\mathrm{pH}$ (Twomey et al., 2003).

Although the number of lactateproducing bacteria, such as Lactobacillus spp. and Bifidobacterium spp., was not determined in the present study, the lower faecal $\mathrm{pH}$ of dogs fed the highest FOS level may be correlated with higher growth and activity of these microorganisms in the large intestine. For instance, Middelbos et al. (2007), studying different fibre sources (cellulose, beet pulp, FOS, and MOS), reported higher concentration of Bifidobacterium spp. and Lactobacillus spp. in the faeces of dogs fed fermentable fibres as compared to those fed cellulose. Russell (1998) also found higher Bifidobacterium spp. levels in the faeces of dogs fed $1 \%$ FOS or $3 \%$ chicory. Swanson et al. (2002a) fed dogs purified diets with FOS-free ingredients, and observed higher concentrations of Lactobacillus spp., butyrate, lactic acid, in addition to Bifidobacterium spp., as well as lower Clostridium perfringens numbers when dogs were supplemented $4 \mathrm{~g}$ FOS/day in a gelatine capsule as compared to those receiving $4 \mathrm{~g}$ sucrose/day. However, no differences in faecal $\mathrm{pH}$, score, DM, or faecal output were detected. Middelbos et al. (2007) evaluated different fibre sources (celullose, beet pulp, FOS, and mannan oligosaccharide - MOS) and reported higher levels of Bifidobacterium spp. and Lactobacillus spp. in the faeces of dogs fed fermentable fibre as compared to those fed cellulose.

There was no effect of treatments on faecal ammonia concentration or faecal output $(P>0.05)$ (Table 2). The maximum level of $0.095 \%$ FOS probably was not sufficient to change the synthesis of nitrogenous compounds in the large intestine. Swanson et al. (2002b) also did not observe any influence of FOS on faecal ammonia concentration when supplementing dog with 2 g FOS/day; however, in another study by SWANSON et al. (2002a), dogs fed $4 \mathrm{~g}$ FOS/day presented reduced faecal ammonia levels.

Intestinal

microorganisms metabolize nitrogenous compounds, generating putrefactive catabolites, such as ammonia, biogenic amines, and phenol, which are responsible for faecal foul odour. Furthermore, many of these catabolites may negatively influence gut health, because high ammonia 
concentrations are thought to disturb the mucosa cell cycle and contribute to colon carcinogenesis (Lin \& Visek, 1991).

Nitrogen metabolism by the colonic may be influenced by substrate availability, particularly of dietary carbohydrates. Fermentable carbohydrates, including FOS, may decrease the concentration of putrefactive compounds by providing gut microflora with an additional energy supply (Remesy \& Demigne, 1989). When energy (carbohydrate) supplies are limited, bacteria ferment amino acids to SCFA and ammonia to obtain energy. However, if a sufficient energy is supplied, the luminal concentrations of nitrogenous compounds decrease and the concentration of faecal $\mathrm{N}$ (bacterial mass) increase (Swanson et al., 2002a).

\section{CONCLUSION}

The dietary supplementation of $0.095 \%$ FOS positively influences faecal quality of dogs, improving faecal consistency and reducing faecal $\mathrm{pH}$. However, there were no improvements on faecal ammonia. Future studies are required to determine the best FOS supplementation level in commercial dog foods, considering that the studies have yielded contradictory results due to the wide variation of supplemented levels, cumulative effects of ingredients rich in fermentable polysaccharides used in the experimental diets, and different adaptation periods of dogs to the experimental diets.

\section{REFERENCES}

ASSOCIATION OF THE OFFICIAL ANALITICAL CHEMISTS - AOAC. Official and tentative methods of analysis, 16.ed. Arlington: AOAC International, 1995. 1025p.

BEYNEN, A.C. Nutraceuticals: Claims vs. Evidence. In: PRODUCTION SYMPOSIUM TRADE SHOW - PET FOOD FORUM, 2003, Chicago. Anais... Chicago. p.169-175, 2003.
CUMMINGS, J.H., ENGLYST, H.N.

Gastrointestinal effects of food carbohydrate.

American Journal of Clinical Nutrition, v.61, p.938-945, 1995.

GIBSON, G.R., ROBERFROID, M.B. Dietary modulation of the human colonic microbiota: introducing the concept of prebiotics. Journal of Nutrition, v.125, n.6, p.1401-1412, 1995.

HERSCHEL, D.A. et al. Absorption of volatile fatty acid, $\mathrm{Na}$, and $\mathrm{H} 2 \mathrm{O}$ by the colon of the dog. American Journal of Veterinary Research, n.42, p.1118-1124, 1981.

HUSSEIN, S.H., et al. Selected

fructooligosaccharide composition of pet-food ingredients. Journal of Nutrition, v.128, p.28032805, 1998.

Lin, H.C.; Visek, W.J. Large intestinal pH and ammonia in rats: dietary fat and protein interactions. Journal of Nutrition, v.121, n.6, p.832-843, 1991.

MIDDELBOS, I.S.; FASTINGER, N.D.; FAHEY Jr., G.C. Evaluation of fermentable oligosaccharides in diets fed to dog in comparison to fiber standards. Journal of Animal Science, v.85, p.3033-3044, 2007.

NATIONAL RESEARCH COUNCIL - NRC. Nutrient Requirements of Dogs and Cats. Washington: National Academy Press., 2006. 428p.

REMESY, C.; DEMIGNE, C. Specific effects of fermentable carbohydrates on blood urea flux and ammonia absorption in the rat cecum. Journal of Nutrition, v.119, p.560-565, 1989.

RUSSELL, T.J. The effect of natural source of non-digestible oligosaccharides on the fecal microflora of the dog and effects on digestion. Copyright Friskies-Europe: Friskies R \& D Center, St. Joseph, 1998.

SÁ FORTES, C.M.L. Valor nutricional de ingredientes energéticos e protéicos para cães. Jaboticabal: Universidade Estadual Paulista, 2005. 82p. Tese (Doutorado em Zootecnia) - Universidade Estadual Paulista, 2005.

SAS INSTITUTE. Statistical analysis system: users guide. Cary, 1999.

SCHNEEMAN, B.O. Fiber, inulin and oligofructose: similarities and differences. Journal of Nutrition, v.129, n.7, p.1424-1427, 1999.

STRICKLING, J.A., et al. Evaluation of oligosaccharide addition to dog diets: influences on nutrient digestion and microbial populations. 
Animal Feed Science and Technology, v.86, n.2, p.205-219, 2000.

SWANSON, K; GRIESHOP, C.M.;

FLICKINGER, E.A. et al. Fructooligosaccharides and lactobacillus acidophilus modify gut microbial populations, total tract nutrient digestibilities and fecal protein catabolite concentrations in healthy Adult dogs. Journal of Nutrition, v.132, n.12, p.3721-3731, 2002a.

SWANSON, K; GRIESHOP, C.M.;

FLICKINGER, E.A. et al. Supplemental fructooligosaccharides and mannanoligosaccharides influence immune function, ileal and total tract nutrient digestibilities, microbial populations and concentrations of protein catabolites in large bowel of dogs. Journal of Nutrition v.132, p.980-989, 2002b.

TWOMEY, L.N.; PLUSKE, J.R.; ROWE, J.B. et al. The effects, of added fructooligosaccharide (Raftilose®P95) and inulinase on faecal quality and digestibility in dogs. Animal Feed Science and Technology, v.108, p.83-93, 2003.

WALTER, M.; SILVA, L.; PERDOMO, D.

Biological response of rats to resistent starch.

Revista do Instituto Adolfo Lutz, v.64, n.2, p.252-257, 2005. 